\title{
飛鳥の須彌山石
}

\section{The Mt. Sumeru Stone of Asuka}

外村 中

\section{SOTOMURA, Ataru}

ヴュルツブルク大学

University of Würzburg

Key Words : 1. 飛鳥 2. 須彌山石 3. 須彌山図

1. Asuka 2. Shumisen 3. Sumeru

\section{摘要}

近年注目されている説によれば、飛鳥の須彌山石は、 夷狄が当時の日本の朝廷に対して行う服属儀礼のための 装置であったらしいとされる。そして、その儀礼は帝釋 天や四天王に関連する神聖なあるいは呪術的なものであ ったらしいとされる。さらには、『俱舍論』にもとづき つつ、須彌山石と東大寺大仏蓮弁の須彌山図とには共通 点が見られるので、須彌山石は意匠的にも須彌山を象徵 したものであろうとされる。しかしながら、『日本書紀』 や『俱舍論』などの内容を確認してみると、以上のよう に解釈することは適切ではなさそうである。須彌山石は、 文化力誇示のための装置と見るほうがよいであろう。ま た、その意匠についても、さらに検討が必要であろう。

\section{はじめに}

小稿にいう飛鳥の「須彌山石」とは、明治 35 年に石神 遺跡で発見された石造物を指し1)、『日本書紀』に記さ れたものは、「須彌山像」と表記することにする。須彌 山石は、少なくとも須彌山像の一つと思われ、日本庭園 史を語るとき最初に取り上げられる代表的な構造物の一 つであり、ある種の噴水施設であったことは周知のとお りである(図1)。

近年注目されている説（以下では「その説」と呼ぶ） によれば2)、須彌山石はまさに須彌山像のことで、それ は夷狄が当時の日本の朝廷に対して行う服属儀礼のため の装置であったらしいとされる。そして、その儀礼は帝
釋天や四天王に関連寸る 神聖なあるいは呪術的な ものであったらしいと考 えられている。さらに、 須彌山石は意匠的にも仏 教思想にもとづく須彌山 を象徴したものであろう とされる。したがって、 もしその説が正しければ、 須彌山石は実際には須彌 山を象徵したものではな い可能性があるという指 摘などは否定されてしま

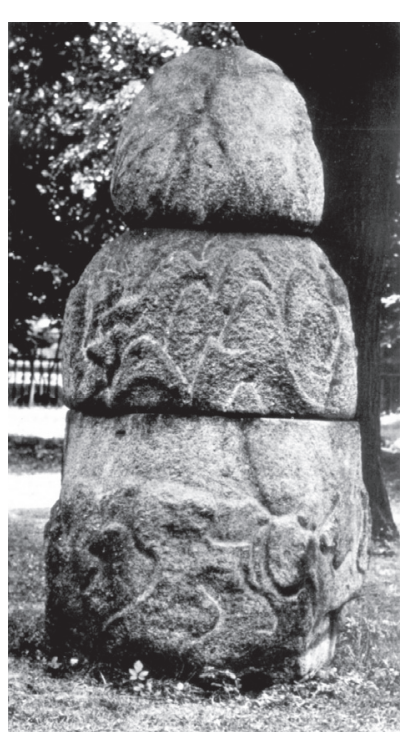

図1 須彌山石
う ${ }^{3)}$ 。その説はとくに美術史の分野で支持を集めており、 定説になりつつある ${ }^{4)}$ 。

以上のような状況であるが、筆者は、その説をただち に定説として受け入れることには躊躇を覚える。という のは、次のように考えるからである。

(1)須彌山石は、服属儀礼のための装置であったというよ りは、むしろ文化力誇示のための装置であったと見るほ うが適切なようである。なお、小稿にいう文化力誇示と は、饗宴の会場で相手が驚くような物珍しい設備や催し を示す力があるのを誇ることをいう。実のところ、文化 力誇示のための装置であったとする解釈は、その説が発 表される以前からの説であるが5)、その説よりも依然有 効であるように思われてならない。たとえば近い時代の 
中国において、塞外民族に対する文化力誇示のために、 隋の煬帝(604-617 在位)が散楽（サーカス）を大々的に 行わせている ${ }^{6)}$ 。従来の研究では注意が払われていない が、その時の状況と飛鳥の須彌山像が作られたときの状 況とには類似性が認められそうである。

(2)その説は、『俱舍論』にもとづきつつ、須彌山石と東 大寺大仏蓮弁に見られる須彌山図（8 世紀、とりあえず

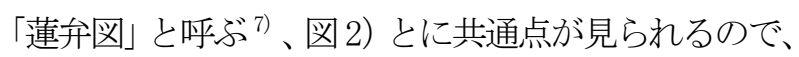
須彌山石は意匠的にも須彌山を象徽したものであろうと する。しかしながら、両者を『俱舍論』の内容と詳しく 比較してみると、そのように考えることは妥当ではなさ そうである。

そこで、小稿では、飛鳥の須彌山石に関連する基礎的 な情報、蓮弁図の特徵、『俱舍論』の内容などを確認し ながら、以上のように考える理由を整理してみたい。

\section{1. 飛鳥の須彌山石は服属儀礼のための装置であったか}

\section{(1) 須彌山像亡須彌山石}

『日本書紀』には、須彌山像について四つの記事が見 られる。確認しておこう。とりあえず以下では、「饗」 は「…のために宴を催した」と訳すが、その説にしたが えば、「・に服属儀礼を行わせた」ということになろう。

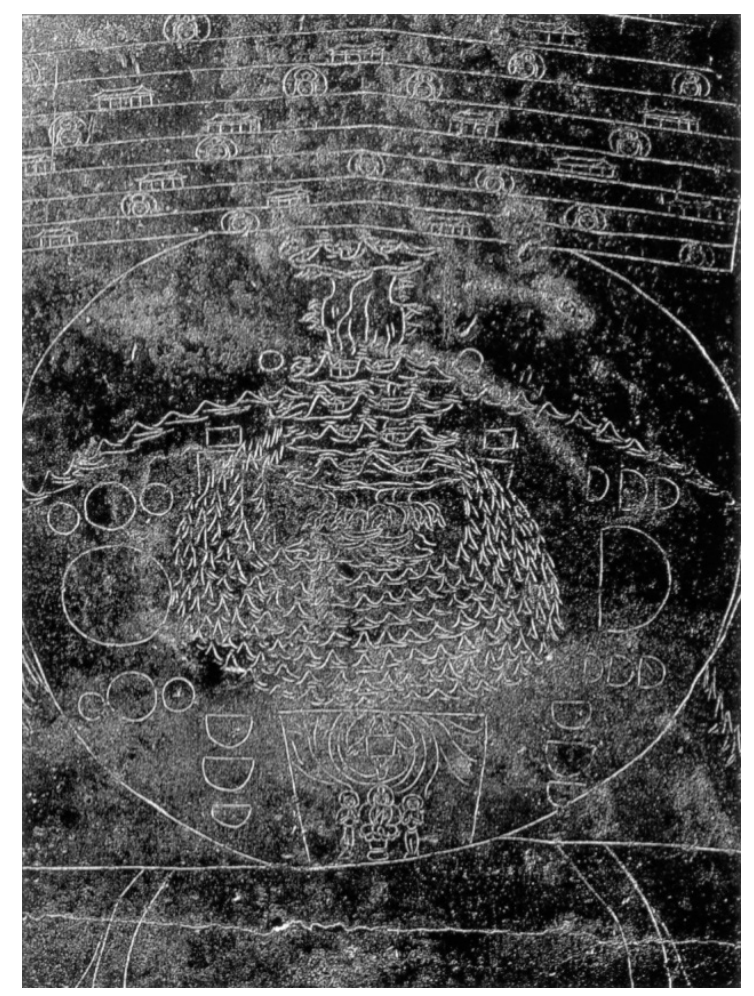

図2 東大寺大仏蓮弁の須彌山図
(1)『日本書紀』巻二十二、推古天皇二十年 (612) 是歳条 「この年、百済国より来た者があった。…その人が言う には、『‥山岳の形を構えることができる。…』。 そこで、須彌山の形および只橋を南庭に構えさせた。 ${ }^{8)}$ 以上は、日本における須彌山像についての記録の初例で ある。

(2)『日本書紀』巻二十六、斉明天皇三年 (657) 七月条「三 年秋七月三日、覩貨邏国の男二人と女四人が筑紫に漂着 した。…こで、早馬を使って呼び寄せた。十五日、須 彌山像を飛鳥寺の西に作った。且（さらに）孟蘭盆会を

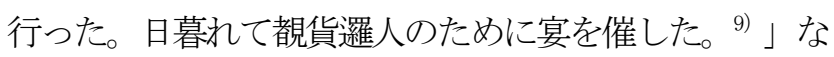
お、原文の「且（さらに）」は対句と見なして「旦（朝 早く）」の誤りとする説もあるが ${ }^{10)}$ 、旦に孟蘭盆会を行 った理由が現在のところ筆者にはよくわからない。たと えば、中国における孟蘭盆会の代表例として則天武后の 如意元年 (692) に行われたものが有名であるが、その状 況を記した楊昫の「孟蘭盆賦」によれば、それは夕方近

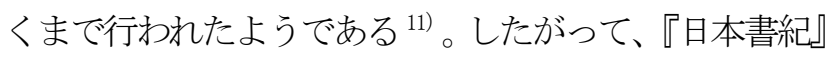
の以上の箇所は国史大系本など諸本に見られる「且」に したがっておきたい。

(3)『日本書紀』巻二十六、斉明天皇五年 (659) 三月条「 (三 月）十七日、甘檮丘の東の川のほとりに、須彌山を造り、 陸奥と越の蝦夷のために宴を催した。 ${ }^{12)} 」$ なお、これは、 『日本書紀』が記す当時の状況から見て、蝦夷の定例的 な朝貢の機会に行われたものと考えられている ${ }^{13)}$ 。

(4)『日本書紀』巻二十六、斉明天皇六年 (660) 五月条「こ の月（五月）、・.また、石上池のほとりに、須彌山を作 った。寺の塔のように高かった。肃愼の四十七人のため に宴を催した。14)」なお、これは、『日本書紀』が記す 当時の状況から見て、阿倍比羅夫による遠征の成果によ るもののようである ${ }^{15)}$

一方、須彌山石は、明治 35 年に奈良県高市郡飛鳥村の 石神というところで発見された ${ }^{16)}$ 。諸説あるものの、そ の発見の場所や遺跡の状況などから考えて、須彌山石は 少なくとも『日本書紀』に記された須彌山像の一つのよ うである。その説では、斉明紀に見られる三例は同一物 であろうとされ、あるいは推古紀のものが引き継がれた 可能性もあるとされる ${ }^{17)}$ 。確証は得られないが、その説 のように考えられないことはないであろう。なお、須彌 山石は、上中下の三段の石組みが発見されているが、中 
段と下段はうまく組み合わないので、本来はその間にも う一段あったと考えられている ${ }^{18)}$ 。

\section{（2）服属儀礼のための装置であるとする説}

その説では、須彌山石は帝釋天や四天王が坐す須彌山 を象徴したもので、その前で服属儀礼すなわち夷狄が当 時の日本の朝廷に服属を誓う儀式（誓約）が行われたの であろうと考えられている ${ }^{19)}$ 。では、どのような点を理 由にそのように考えられているかといえば、正確なとこ ろはそれぞれの論文をもって確認してほしいが、大方次 のような点が主たる理由のようである。

(1)夷狄による服属のための誓約の例がある。たとえば、 次がそうである。

『日本書紀』敏達天皇十年 (581) 閏二月条「十年春閏 二月に、蝦夷の数千人が辺境に侵入して騷ぎを起こした。 そのため、その首領である綾糟らを呼び奇せた。…この ような事態に、綾糟らはおそれかしこまり、意外にも泊 瀬川の中に下りて、三諸岳（三輪山）に向かって、水を す寸って誓って言った、『私ども蝦夷は、今より後は子 棌の続きます限り、忠誠心をもって、天皇にお仕えいた します。…』と。 ${ }^{20) 」 ~}$

(2)飛鳥寺の西は神聖な場所であったらしく、そこの大槻 の樹の下での誓約の例がある。たとえば、次がそうであ る。なお、須彌山石は、その近くに構えられたものであ る。

『日本書紀』孝徳天皇即位前紀 (645) 六月条「 (六月) 十九日に、天皇と皇祖母尊と皇太子は、大槻の樹の下に、 群臣を呼び集められ、誓って言われた、『…としてよ り後は、天皇は誤った政道を行うことはなく、臣下は天 皇に対して背かない。…』と。 ${ }^{21)}$

(3)須彌山石は、斉明天皇三年に孟蘭盆会が行われた日に 作られている。したがって、仏教の教義にもとづくもの と思われ、須彌山石が置かれた場所は神聖なあるいは呪 術的な場所であったと考えられる22)。なお、これによれ ば、須爾山石は仏教に関連する神聖なあるいは呪術的な 儀礼の装置であったといってよいであろう。

(4)帝釋天や四天王に対しての誓約の例がある。たとえば、 次がそうである。

『日本書紀』天智天皇十年 (671) 十一月条「（十一月） 二十三日、大友皇子は内裏の西殿の織物の仏像の前にい た。左大臣である蘇我赤兄臣と、右大臣である中臣金連
と、蘇我果安臣と、巨勢人臣と、紀大人臣が付きしたが っていた。大友皇子は手に香炉を取り、先に立ち上がっ て誓って言った、『六人は心を同じにして、天皇の詔を 承る。もし違う者あれば、必ずや天の罰を受けよう。 云々。』と。そこで、左大臣である蘇我赤兄臣らは、手 に香炉を取り、順にしたがい立ち上がり、泣きながら誓 って言った、『臣ら五人は殿下にしたがい天皇の詔を承 る。もし違う者あれば、四天王が打とう。天神と地祇も また罰を加えよう。三十三（帝釋天を主とする須彌山 山頂の天たち）がそのことを知れば、子孫は絶え、家門 は必ずや亡びよう。云々』と。 ${ }^{23)}$

(5)帝釋天や四天王は須彌山に住む。たとえば、『俱舍論』 には、三十三天と帝釋天について、次のようにある。

『阿毘達磨俱舍論』巻十一「論じて曰く。三十三天は 須彌山の頂上に住んでいる。…頂の中央に宮がある。 そこは善見といわれる。…とこは帝釋天が都する大城で ある。 ${ }^{24) 」 ~}$

また、四天王については、大方次のようにある。

『阿毘達磨俱舍論』巻十一「論じて曰く。須彌山には 四つの張り出しがある。‥この四つの張り出しは須彌山 の下半分にある。（したがって、下から四つ目の張り出 しの位置は須彌山のちょうど半分の高さに当たる。）… 四つ目の張り出しには、四天王とその春属が住んでいる。 25) 」

以上のような点などを理由に、その説では、須彌山石 は帝釋天や四天王に関連する神聖なあるいは呪術的な服 属儀礼のための装置であったと考えているようである。 なお、その説では、帝釋天や四天王と関連づけられてい るので、もしその説が正しければ、須彌山石は明らかに 須彌山を象徵したものであることになる。この点は、須 彌山石の意匠を考えるとき、重要になってくるであろう。

(3) その説の問題点

以上を見るに、その説は、一つの可能性としてなら成 立する仮説であろう。しかしながら、たとえば、以下に 見るように、須彌山像を用いて服属儀礼を行った例は確 認できない。したがって、その説をただちには定説とし て受け入れることは難しい。

(1)敏達天皇十年の夷狄による服属のための誓約の例は、 三輪山に向かってのものであり、須彌山像に向かっての ものではない。 
(2)天智天皇十年の帝釋天や四天王に対しての誓約の例は、 服属のための誓約ではなく、同志の間での誓約である。 また、それは織物の仏像の前で行われたものであり、須 彌山像の前で行われたものではない。

(3)斉明天皇三年の例では、孟蘭盆会が行われた日に須彌 山像が作られているが、孟蘭盆会を行う理由を記す『孟 蘭盆經』を見るに、孟蘭盆会と須彌山像の関係はわから ない。孟蘭盆会は、死後も苦しんでいる父母を救うため に、七月十五日に仏および僧に食べ物をささげて供養を 行うものである ${ }^{26)}$ 。『孟蘭盆經』によれば、天神や地神 や四天王などさえどうすることもできないので27)、多く の僧の力に頼るべく、仏が孟蘭盆会を行うことを説いた といわれる。したがって、孟蘭盆会では、とくに須彌山 像は必要ないように思われる。あるいは、斉明天皇三年 七月十五日に須彌山像が作られたのは、孟蘭盆会よりは、 むしろ覩貨邏人を呼び寄せたことに関係があるかもしれ ない。あるいは、本来二つの記録であった、須彌山像を 作り覩貨邏人のために宴を催した記録と孟蘭盆会を行っ た記録を『日本書紀』の撰者が混成し、一つの記録にし た可能性もあるかもしれない。『日本書紀』に見られる 須彌山像が作られた他の例では、仏教との関連は見いだ せない。したがって、孟蘭盆会の日に須彌山像が作られ たことを記寸斉明天皇三年のこの記録だけをもって、須 彌山像を仏教の教義にもとづく神聖なあるいは呪術的な 儀礼のための装置と見なしてしまうことは適切ではな いであろう。

(4)斉明天皇三年の例に見る覩貨邏人の男女は、首領ある いは使節であったとは記されていない。したがって、国 家を代表する人物ではなかったように思われるが、その ような人たちに服属儀礼を行わせる必要があったのであ ろうか。あったといいきることは難しいであろう。

(5)斉明天皇三年の例については、須彌山像が作られたの が十五日で、それは四天王等が人間の行状を観察する日 である六齋日（八、十四、十五、二十三、二十九、三十 日）に当たるので、その日の行事（儀礼）が四天王の巡 行を意識して設定されたことは間違いないとする解釈も ある ${ }^{28)}$ 。しかしながら、夷狄の漂着ではなく定例的な朝 貢であるため、より計画的に行われたであろう斉明天皇 五年の例では、六齋日ではない十七日に須彌山像が造ら れている。したがって、須彌山像を六齋日との関係から
四天王に関連する儀礼のための装置と決めつけてしまう ことはできないであろう。

6)斉明天皇五年の例については、蝦夷の定例的な朝貢の 機会であれば、朝貢自体が服属を示寸ものであるから、 須彌山像の前でわざわざ服属儀礼を行わせる必要があっ たのであろうか。もちろん、なかったと断定することは できないが、あったといいきることも難しいであろう。 (7)斉明天皇六年の例は、須彌山像の前で服属儀礼を行わ せた可能性が最も高い例としてあげられよう。しかしな がら、その当時すでに夷狄の人々も帝釋天や四天王につ いて理解していたのであろうか。ちなみに、蝦夷につい ては、仏教によって蝦夷の教化を試みることは持統天皇 の時代における特徴的な蝦夷経営策といわれる ${ }^{29)}$ 。ある いは神仏習合という視点から、須彌山像は、当時の日本 の朝廷にとっては帝釋天や四天王の坐す須彌山を象徽し たものであったが、夷狄にとっては彼らが崇める山を象 徵したものであったと解釈をすることもできるかもしれ ない。そして、そのような須彌山像の前で服属儀礼が行 われたことを示すのが斉明天皇六年の記事であると見な すことができるかもしれない。しかしながら、そのよう に考えるよりも、須彌山像は饗宴の会場に物珍しい設備 をして文化力を誇示し、朝に同化させようと努力したも のの現れとするほうが30)、無理がない解釈であろう。

以上のような理由により、その説を否定してしまうこ とはできないものの、その説にただちにしたがうことは 難しいのである。

\section{(4) 石人像}

そして、なによりも、その説を受け入れることを困難 にするのが、石人像（道祖神像）の存在である（図 3) 31)。石人像は、須爾山石と石質も同じであり、作風も同 じで、そして、同じ場所からほとんど相接して出土した ものであり、内部構造にも共通したところがあるので、 もともと石人像と須彌山石の両者は同じ計画の下に考案 されたものであろうと考えられている ${ }^{32)}$ 。この石人像と 仏教の関係が理解できない。飛鳥の石人像を伎楽に関連 するものとし、伎楽は日本においては仏教の法会におい て演じられた点から、石人像と須彌山石を結びつける解 釈がある ${ }^{33)}$ 。しかしながら、『日本書紀』を見るに、斉 明天皇三年の記事以外は伀教の法会に関わるものではな いので、ただちにはその解釈にはしたがえない。また、 
須彌山石の近くに石人像を 置くことができたのである から、その説にいわれるよ うな神聖なあるいは呪術的 な服属儀礼が行われていた のであれば、帝釋天や四天 王の像が置かれていてもよ さそうに思われる。ところ が、それらの像は発見され ていない。もちろん、須彌 山像で象徴させていたから 不要であったと考えること もできるかもしれない。し かしながら、かりにそうで あれば、石人像は帝釋天や 四天王よりもさらに現実的 なものとして儀礼のために

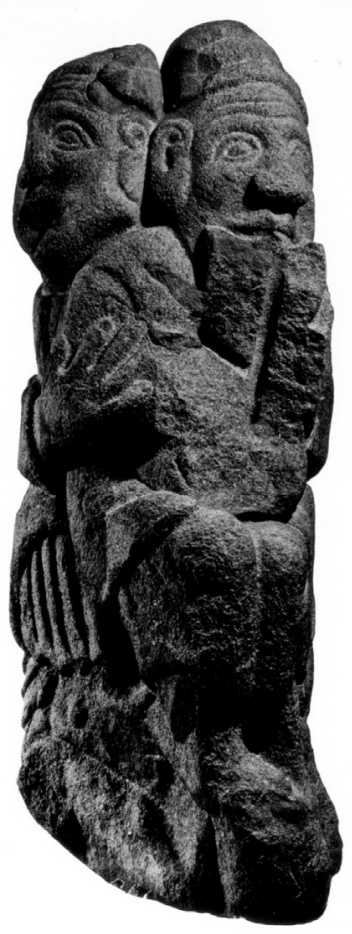

図3 石人像(道祖神像)
より重要であったとも思われるので、ますます服属儀礼 のためになぜ石人像を置いたか理解することが困難にな る。したがって、石人像の存在は、服属儀礼のためでは なかった可能性を示寸もののように思われてならない。 ちなみに、その説では石人像については言及されていな いが、その理由はわからない。

\section{(5) 隋の煬帝の散楽}

では、その他の可能性として、何があげられるかとい えば、やはり文化力誇示のための装置であったという点 があげられよう。もちろん、服属儀礼のための装置であ れ、文化力誇示のための装置であれ、広義にはどちらも 服属に関連寸るものであることには違いはない。しかし ながら、この違いは須彌山石を考える上では大きい。な ぜなら、帝釋天や四天王に関連する神聖なあるいは呪術 的な服属儀礼のための装置であれば、他の東アジア諸国 において類例が確認されていない特殊なものになるが、 一方、文化力誇示のための装置であれば、状況的な類例 が近い時代の中国に見いだされるからである。そして、 その中国における類例としてあげられるものが、隋の煬 帝が帝都洛陽で大々的に行わせた散楽（サーカス）であ る。

飛鳥の須彌山石についてのその説では、須彌山像は孟 蘭盆会が行われた日に作られているので、須彌山石は仏
教の教義にもとづく神聖なあるいは呪術的なものであっ たように考えられている。しかしながら、必ずしもその ように考えられるわけではないことは、先に指摘したと おりである。また、中国の散楽についての記録にもとづ き東アジア的視点に立って見ると、「須爾山」というだ けでは、神聖なあるいは呪術的なものであったとはいい きれない。というのは、梁代(502-557) の散楽に須彌山を 演目にしたものが見られるからである ${ }^{34)}$ 。

『隋書』によれば、梁代では宮中における元旦の儀礼 において、須彌山伎が演じられていた。たとえば、二十 六番目から三十番目の演目は、次のとおりである。

『隋書』巻十三「二十六には長蹻伎を行う。二十七に は須彌山、黄山、三峽などの伎を行う。二十八には跳鈴 伎を行う。二十九には跳劍伎を行う。三十には橂侄伎を 行う。 ${ }^{35)} 」$

以上の須彌山伎が散楽であることは、前後の演目名か ら理解されよう。また、次の『通典』の「散楽」の項の 内容が参考になろう。

『通典』巻百四十六「たいていの散楽の多くの技や術 は、いずれも西域を起源としたものである。…梁代には、 長蹻伎、跳鈴伎、躑倒伎、跳劍伎があった。それらはい ずれも今（唐代）でも演じられている。…透三峽伎は、 おそらく今の透飛梯の類であろう。 ${ }^{36)}$

ちなみに、長蹻伎は竹馬乗りのようなものか、跳鈴伎 は鈴を振り回すようなものか、橂倒伎と躑倒伎は逆立ち のようなものか、跳劍伎は剣を投げ回すようなものか、 透飛梯は高く設置された梯子をくぐるようなものかと想 像される。

以上のように散楽の演目にあるのであるから、須彌山 伎は、神聖なあるいは呪術的なものというよりは、人目 を驚か寸物珍しいものであったと考えることができよう。 とすれば、『日本書紀』にいら須彌山像も飛鳥の須彌山 石も、その目的からいえば、あるいは同様なものであっ た可能性が考えられよう。

隋の煬帝は大々的に散楽を行わせたが、それはもとも と東突厥の首領であった啓民可汗 (染汗) に対して誇る ためのものであった。すなわち、散楽は文化力誇示のた めの催し、あるいは装置であったようである。『隋書』 には、おおよそ次のような内容が見られる。

『隋書』巻十五「ことの始まりは、北齊の後主 (565-577 
在位) の武平年間 (570-576) に、魚龍爛漫、俳優、朱儒、 山車、巨象、拔井、種瓜、殺馬、剥驢など、奇怪で尋常 ではない演技が数多くあった。それらは百戯と呼ばれた。 北周の時代には、宣帝（578-579 在位）に気に入られて いた鄭譯が、宣帝に上奏し、北齊の散楽（百戯）の芸人 をすべて北周の都である長安に集まらせ散楽を行わせた。 それはおそらく秦の角抵（レスリング）のような催しで あったと思われる。隋の文帝（581-604 在位）の開皇年 間 (581-600) の初めに、芸人はすべて解放となった。隋 の煬帝 (604-617 在位) の大業二年 (606) になって、東 突厥の染干（すなわち啓民可汗）が来朝した。煬帝は染 干に散楽を誇ってみせようと、急いで天下の散楽の芸人 を呼び寄せ、大いに東都洛陽に集まらせた。この時には 芳華苑の積翠池の辺で、煬帝は宮女に散楽を見物させた。 ‥また、神鼇（スッポン）が山を背負ったり、幻人（奇 術師）が火を吐いたりと、変化極まりなく前代未聞の催 しであった。染干は散楽に大いに驚いた。これより、す べての散楽が太常 (宗廟儀礼を掌る機関)で教習された。 毎歳正月、多くの国から来朝した者が留まってのち十五 日になると、（東都洛陽の皇城の正南の）端門の外から 建國門の内まで、連なること八里にわたり散楽の演技場 が列んだ。多くの官吏は通りの両側に見物席を建て、日 暮れから明け方まで思うがままに散楽を見物した。それ は月末になって終わった。…業三年 (607)、煬帝は榆 林（郡名）に行幸した。東突厥の啓民可汗（染干）は、 そこの行宮で煬帝に謁見した。煬帝はまた散楽を行わせ 啓民可汗に見物させた。大業六年 (610) 、多くの四方の 遠国が大いにそれぞれの国の産物を献上した。東突厥の 啓民可汗をはじめ、すべての国の君主が自ら来朝し慶び を述べた。そこで、天津街 (すなわち端門の外から建國 門の内まで）において盛大に百戯（散楽）を行わせた。 天下の寸ぐれた技をもつ芸人はすべて集まった。奢侈を 極めた道具は、真珠や翡翠や金や銀でできていた。立派 に飾った衣装は、錦や毛織や精細な生地で美しい縫い取 りがあった。それらの費用には巨額が投じられた。…百 戯 (散楽) の盛んなことは、過去に例がなかった。散楽 はこれより毎年行われた。 ${ }^{37)} 」$

梁代の散楽の一つである須彌山伎を、ただちに飛鳥の 須彌山石の源流であると主張するつもりはない。しかし ながら、以上を見るに、飛鳥で須彌山像が作られ宴が催
された状況と隋の煬帝が散楽を行わせた状況には相通じ るところがあるように思われる。もちろん、スケールに おいては大いに違いがあるが、どちらも訪れた夷狄のよ うな者に対して文化力を誇示している点では同じと見て よいであろう。したがって、須爾山石は、帝釋天や四天 王に関連する神聖なあるいは呪術的な服属儀礼のための 装置であったというよりは、むしろ隋の煬帝の散楽と同 様な文化力誇示のための装置であったと見るほうが適切 であろうと考えるのである。また、そのように見れば、 須彌山石近くで発見された石人像の存在も問題はなくな るであろう。ちなみに、『隋書』によれば、大業六年の 散楽は、倭からの遣隋使の一行も見物したようである ${ }^{38)}$ 。

\section{2. 須彌山石は須彌山を象徵したものか}

\section{（1）須彌山石と蓮弁図}

その説は、須彌山石と、最も代表的な須彌山図の一つ である東大寺大仏の蓮弁に画かれた須彌山図 (蓮弁図、8 世紀）とに共通点が見られるので、須彌山石は意厈的に も仏典に見られる須彌山を象徴したものであろうとする (図 1 および図 2 を参照) ${ }^{39)}$ 。しかしながら、須彌山石 は蓮弁図と詳しく比較してみると、重要な点で相違が見 られる。たとえば、須彌山石では、山頂の中央付近に建 物が見られない点や根元の水際に龍が見られない点など がそうである。これらの相違は、須彌山石が須彌山を象 徵したものであると断定することを難しくする。したが って、須彌山以外のものを象徴したものとする説を無視 してしまうわけにはいかないように思われる ${ }^{40)}$ 。

その説は、『俱舍論』にもとづきつつ、次の四つの共 通点により、須彌山石は仏典に説か孔る須彌山を象徵し たものであろうとする。

(1)須彌山石は、蓮弁図と同様に、高く屹立する。

(2)須彌山石の上石の山形文の浮彫は、蓮弁図の頂上の訬 利天の山と一致する。忉利天の四峰にもとづくものであ ろう。

(3)須彌山石の中石の山形文の浮彫は、蓮弁図の須彌山の 中腹の四天王や衆天の住む宮殿のある山々に一致する。 (4)須彌山石の下石の水波文の浮彫は、蓮弁図の須彌山の 根元にうちよせる大海の波と一致する。

以上のように、その説はいう。ところが、蓮弁図に見 られる特徵を注意して分析してみると、その説が指摘す 
る共通点には問題がありそうである。蓮弁図の特徵をよ り正確に理解するためには、とくに次の点を再確認して おく必要があろう。

(1)須彌山の高さ。須彌山石も蓮弁図の須彌山も屹立する。 この点については、その説がいうところに問題はない。 ただし、この点だけでは須彌山石が須彌山を象徽したも のであると断定できないことはいうまでもない。

(2)平面。須彌山石は、おおよそ円形である。一方、蓮弁 図の須爾山は、必ずしも明確ではないが、たとえば『俱 舍論』に正方形であるとある点をある程度反映している ように思われる。

(3)断面。須彌山石は、長方形ではない。一方、蓮弁図の 須彌山は、張り出しを除けば、おおよそ長方形である。 これは『俱舍論』に上辺と下辺の長さが等しいとある点 をある程度反映しているように思われる。

(4)山頂の四峰。須彌山石の四峰は、その説が参照する図 を見るに (図4)、上石の下部半面に集まっているので、 山頂の四峰といえるかどうか疑問である。一方、蓮弁図 の山頂に見られる三峰は、『俱舍論』に峰は山頂の四隅 に一つずつあるとある点を反映しているように思われる。 (5)山頂。須彌山石では、山頂の中央付近に建物は見られ ない。一方、蓮弁図は、『俱舍論』に山頂の中央には帝 釋天の善見城（善見宮）があるとある点を反映している ように思われる。

(6)四層の張り出し。須彌山石では、四層は明確ではない。 一方、蓮弁図では、須彌山の半分から下に四層の張り出 しがある。この四層の位置と間隔は『俱舍論』の内容に 一致する。

(7)根元。須爾山石では、根元の水際に龍が見られない。

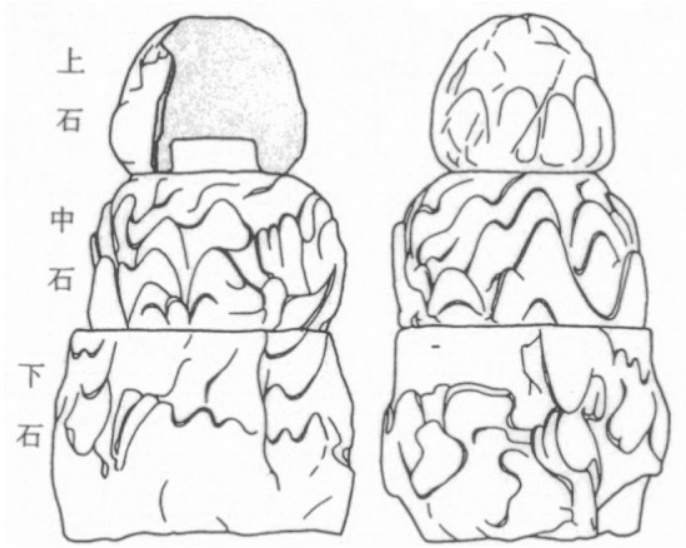

図4 須彌山石図
一方、蓮弁図では、複数の龍が見られる。これは、『俱 舍論』に記された龍についての内容をある程度反映して いるように思われる。その説では、とくに波に注目して いるが、波の重要性はわからない。一方、蓮弁図や『俱 舍論』の他にも龍の存在を示寸仏典は多いので、根元の 水際あるいは付近に龍が見られるかどうかのほうが重要 であるように思われる。

\section{（2）蓮弁図と『俱舍論』}

蓮弁図の須彌山の図像は、『世記經』、『起世經』、 『立世論』、『婆沙論』、『大智度論』、『瑜伽論』、 『正法念處經』など須彌山について詳しい多くの仏典の 内容と比較してみるに、『俱舍論』の内容と最も関連が ありそうに思われる。蓮弁図と『大智度論』など他の仏

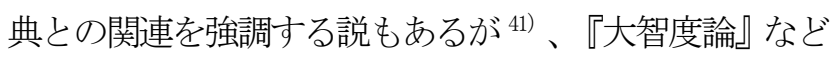
の仏典では、とくに蓮弁図に見られる四層の張り出しが 説明できない ${ }^{42)}$ 。以下では、蓮弁図と比較しながら『俱 舍論』の内容を確認しておこう。

(1)須彌山の高さ。蓮弁図の須彌山は屹立する。一方、『俱 舍論』によれば、須彌山の高さは、海抜八万由旬である。 八万由旬というのは、要するに非常に高いことを意味す る。ちなみに、由旬については諸説紛々で、たとえば唐 の玄牀の『大唐西域記』には、一由旬は十六里（唐の大 尺でなら約 $8.5 \mathrm{~km}$ ) とする説などが見られる ${ }^{43)}$ 。

『阿毘達磨俱舍論』巻十一「論じて曰く。ここのよう に九つの山は金輪の上にそびえている。いずれの山も水 中にある部分は八万由旬ある。須彌山は水上にある部分 も同じである。 ${ }^{44) 」}$

(2)須彌山の平面。平面とは、水平方向に切って真上から 見たものとする。蓮弁図の須彌山は、平面が円形のよう でもあるが、須彌山に見られる縦の筋や須彌山を取り囲 む山などから判断するに、必ずしも正円ではない。平面 が円形であるとする仏典（正確には漢訳仏典）は知られ ない。一方、『俱舍論』によれば、須彌山の平面は一辺 八万由旬の正方形である。

『阿毘達磨俱舍論』巻十一「論じて曰く。…その山頂 の四面の一辺はそれぞれ八万由旬で、下（おそらく水面 部分）の四辺のそれぞれの長さと同じである。 ${ }^{45)}$ (3)須彌山の断面。断面とは、垂直に切って真横から見た ものとする。蓮弁図の須彌山の断面は、張り出しを除け ば、おおよそ長方形である。断面が長方形であるとする 
仏典は知られない。一方、『俱舍論』によれば、以上の 平面で見たように上辺（すなわち山頂部分）と下辺（お そらく水面部分）の長さは等しく八万由旬で、また先で 見たように高さは八万由旬あるので、断面は一辺八万由 旬の正方形のようである ${ }^{46)}$ 。なお、『俱舍論』には、断 面は上辺二万由旬、下辺八万由旬、高さ八万由旬の台形 であるとする異説があることが紹介されている ${ }^{47)}$ 。有部 正統派の『婆沙論』は、この異説のほうを定説とする ${ }^{48)}$ 世親（ヴァスバンドゥ）の『俱舍論』は基本的には有部 であるが、一部に経量部の立場から批判を加えたところ があるといわれる。あるいは、この箇所はその一例かも しれない。ちなみに、世親の『俱舍論』を批判し有部の 正義を表明するために記されたといわれる衆賢（サンガ バドラ）の『順正理論』の内容は、『婆沙論』の内容と 同じである ${ }^{49)}$ 。

(4)山頂の四峰。蓮弁図の須彌山の山頂には、三つの峰が 見られる。図が示寸状況から判断寸るに、山頂には四つ の峰があると見てよいであろう。一方、『俱舍論』によ れば、次のとおりである。

『阿毘達磨俱舍論』巻十一「論じて曰く。…山頂の四 隅にそれぞれ一つの峰がある。その高さと幅はそれぞれ 五百由旬ある。金剛手という藥叉神が住んでいる。 (5)山頂の中央。蓮弁図の須彌山の山頂には、中央付近に 建物のようなものが見られる。一方、『俱舍論』によれ ば、次のとおりである。

『阿毘達磨俱舍論』巻十一「論じて曰く。…山頂の中 央に宮がある。そこは善見といわれる。…そこは帝釋天 が都する大城である。 ${ }^{51)}$

66四層の張り出し。蓮弁図の須彌山には、須彌山の半分 から下に四層の張り出しが見られる。それは、須彌山の 半分から下を四等分する。これは『俱舍論』の内容と一 致する。一方、他の仏典では説明することが難しい ${ }^{52)}$ 。 この点は、蓮弁図の須彌山が『俱舍論』に依拠している 可能性が大きいことを示すものとして、とくに注目すべ きであろう。『俱舍論』によれば、次のとおりである。

『阿毘達磨俱舍論』巻十一頌して曰く。須彌山に四 層の張り出しあり。それぞれ一万由旬ずつ離る。張り出 すこと、一万六千、八千、四千、二千由旬なり。堅手お よび持㱗、恒憍および四天王の衆が順に従い四層に住む。 53) 」
『阿毘達磨俱舍論』巻十「（以上の頌について）論 じて曰く。須彌山には四層の張り出しがある。まず水際 より第一層まで一万由旬離れている。中間も同様で、第 三層より第四層もまた一万由旬離れている。この四層の 張り出しは須彌山の下半分に張り出しめぐっている。第 一層は一万六千由旬張り出している。第二、第三、第四 層はそれぞれ八千由旬、四千由旬、二千由旬張り出して いる。堅手という藥叉神が第一層に住んでいる。持皲と いう藥叉神が第二層に住んでいる。恒憍という薬叉神が 第三層に住んでいる。これら三神はみな四天王の部下で ある。第四層には四天王およびその多くの春屬がともに 住んでいる。 ${ }^{54)} 」$ なお、以上によれば、蓮弁図の張り出 しの幅は、『俱舍論』の内容に一致しない。

(7)根元の龍。蓮弁図の須彌山は、根元の水際に龍が見ら れる。報告によれば、九匹の龍のようである ${ }^{55)}$ 。一方、 『俱舍論』には、龍の数は同じではないが、次のように ある。

『阿毘達磨俱舍論』巻十一「論じて曰く。…故に世尊 は言われた。『八匹の大龍がいて、それらはみな一劫（と いう長い時）を生きて大地を持す（大地を守りささえる) ことができる』と。 ${ }^{56)}$

8九山。蓮弁図の須彌山の外には、七つの山脈があり、 その外に四大洲があり、さらにその外に一つの山脈が見 られる。これは『俱舍論』の内容と一致する。

『阿毘達磨俱舍論』巻十一「論じて曰く。金輪の上に 九つの大山がある。須彌山が中央に㪘え、残りの八山が 須彌山を取り囲んでいる。八山のうち前の七つを内とい う。(最も内から) 第七番目の山の外に大洲などがある。 その外にさらに鐵輪圍山があり、輪のようにめぐって一 つの世界を取り囲んでいる。

(9)四大洲の位置と形。蓮弁図の須彌山の右には左側が久 けた半月形、手前には台形のような形、左には円形をし た大洲が見られる。また、向こうには隠れて見えないが 附属の洲の形から判断して方形をしたと思われる大洲が あるようである。これは『俱舍論』の内容と一致する。

『阿毘達磨俱舍論』巻十一「論じて曰く。外海の中に 四つの大洲がある。それらは須彌山の四面にあって須彌 山と向き合っている。南贍部洲は北が広く南が狭い。三 辺は長さが等しく、その形は車のようである。南辺はわ ずかに三由旬半あり、他の三辺はそれぞれ二千由旬ある。 
…東勝身洲は東が狭く西が広い。三辺は長さが等しく、 その形は半月のようである。東は三百五十由旬あり、他 の三辺はそれぞれ二千由旬ある。西牛貨洲は円くて満月 のようである。直径は二千五百由旬で、周囲は七千五百 由旬ある。北俱盧洲は形が方座のようで、四辺の長さが 等しく、一辺それぞれ二千由旬ある。 $\left.{ }^{58)}\right) 」$

以上を見るに、すべてまったくそのとおりであるとい うわけではないが、先にあげた蓮弁図の特徽は『俱舍論』 の内容に大方対応しているように思われる。他の仏典の 内容と比較してみるに、蓮弁図の須彌山の図像は、『俱 舍論』の内容をもって最も詳しく説明がつきそうである。 したがって、蓮弁図は『俱舍論』に依拠したものである 可能性が大きいように思われる。ただし、『俱舍論』の みに依拠したものではないようである。というのは、た とえば、南贍部洲の内の図像は『俱舍論』では説明がつ かないからである。

\section{（3）須彌山石は何か不明}

一方、以上を見るに、飛鳥の須彌山石は『俱舍論』に 依拠しているとはいえないであろう。したがって、その 説が指摘する『俱舍論』にもとづく須彌山石と蓮弁図と の共通点は妥当ではないように思われる。では、須彌山 石は、『俱舍論』以外の仏典に依拠したとみれば、問題 はすぐに解決するかといえば、必ずしもそうではなさそ うである。というのは、次のような理由による。

(1)『俱舍論』に依拠していないと思われる須彌山の近い 時代の代表的な例として、たとえば、日本の玉虫厨子の
例（7 世紀）と中国の萬佛寺の例（6 世紀前半）があげら れる（図 5 および図 6) ${ }^{59)}$ 。ところが、それらにおいて も、山頂の中央には帝釋天の善見城と思われる建物があ ったり、あるいは、根元附近には龍が見られたりする。 一方、須彌山石ではそうではない

(2)須彌山石は、四方へ水が噴き出すように工夫されてい る。これに対応するものは蓮弁図に画かれていないだけ ではなく、仏典においても確認できない。

(3)須爾山石の下石の底部分には、ほぞ穴状のくぼみがあ る (図 7） ${ }^{61)}$ 。したがって、下石の下にさらに何かがあ ったらしいが、何があったかは不明である。

以上の点は、須彌山石が須彌山以外の山を象徵したも のであることを示している可能性もあるであろう。少な くとも、その説に見られる説明だけでは、須爾山石は意 匠的にも須彌山を象徵したものであると断定することは できないであろう。

\section{おわりに}

須彌山石は帝釋天や四天王に関連する神聖なあるいは 呪術的な服属儀礼のための装置であったらしいとする説 が、近年支持されている。小稿では、その説のように解 釈するのは適切ではないであろうと考える理由を示した。 孟蘭盆会には須爾山像は必要ではないらしいこと、石人 像の存在、隋の煬帝による散楽についての記録の内容な どから考えて、須彌山石は文化力誇示のための装置と見 るほうがよいであろう。また、その説は、『俱舍論』に

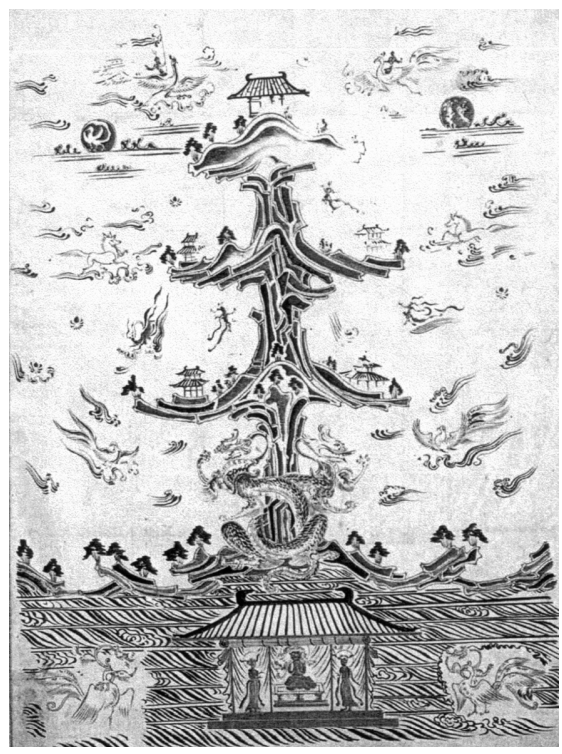

図5 玉虫厨子密陀絵模写須彌山図 (東京国立博物館蔵)

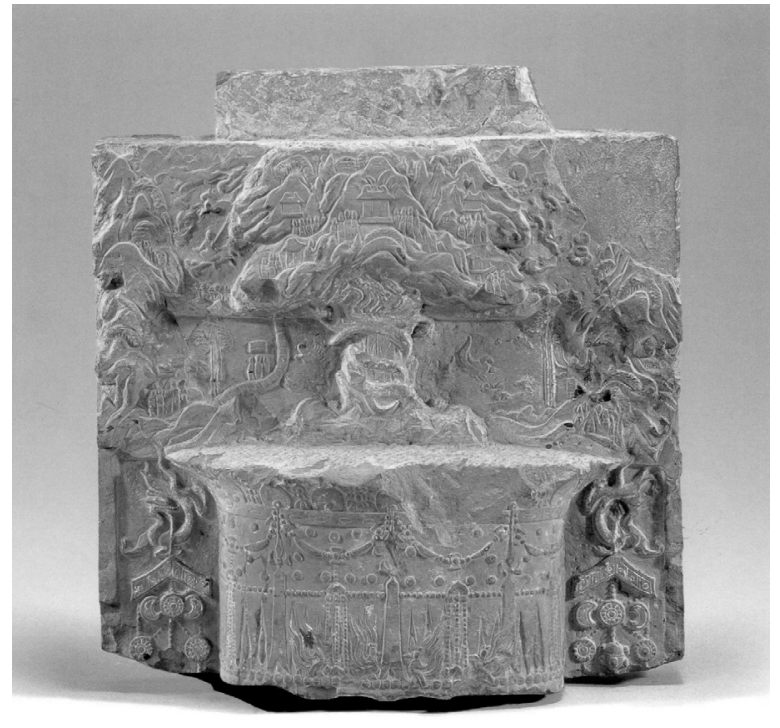

図 6 萬佛寺須彌山図浮彫

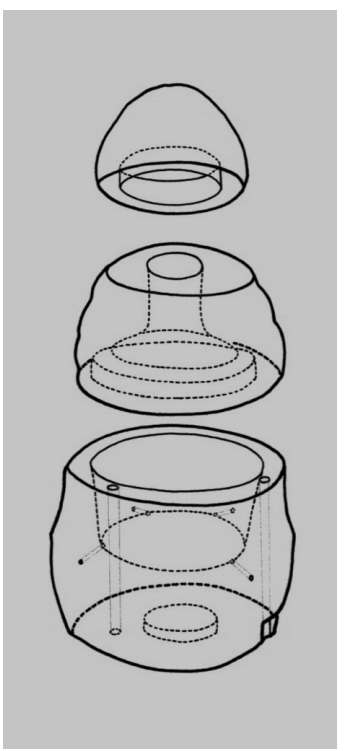

図7 須彌山石図 
もとづきつつ、須彌山石と蓮弁図とに四つの共通点が見 られるから、須彌山石は須彌山を象徵したものであろう とする。しかしながら、蓮弁図は『俱舍論』の内容と関 連が強いが、一方、須彌山石はそうではない。したがっ て、その説にはただちにはしたがえない。ただし、須彌 山石が意匠的に須彌山であると断定できるものではなく ても、当時の人々がそれを須彌山と見立てていた可能性 を否定してしまうことはできない。それゆえ、須彌山石 ははたして何であるかについては、さらに詳しい研究が 必要である。また、当時の中国や百済や新羅などからの 使者に日本の朝廷が須彌山像を示したとする記録は見ら れない。この点は当時の日本人が彼らに須彌山像を示寸 自信がなかったことを示寸ものであるかもしれない。そ のようなものであるから、少なくとも記録に残る須彌山 像の一つであろうと考えられる飛鳥の須彌山石は、当時 の日本人が意識していた国際的な文化水準を検討すると き重要な参考物件となるであろう。したがって、須彌山 石は、日本の一つの石造物としてだけではなく、さらに 様々な角度から分析を行ってみる必要がある対象物であ るといえるであろう。

\section{後記 :}

小稿執筆にあたり、稲本泰生氏、竹浪遠氏、古川千佳 氏から資料提供や助言などをいただきお世話になった。 記して謝意を申し上げたい。

\section{補注および引用文献}

1) 矢島恭介「飛鳥の須彌山と石彫人物について」『國華』58-12 (693)、 1949 年、321-328 頁。奈良国立文化財研究所飛鳥資料館『飛鳥 資料館案内』1975 年、21-25 頁。猪熊兼勝「飛鳥・藤原の園池 遺跡」『佛教藝術』109、毎日新聞社、1976 年、32-41 頁。ま た、飛鳥の石造物については、次がよくまとまっている。猪熊 兼勝「飛鳥の石造物論」『日本の考古学』6 歷史時代、雄山閣 出版、1987 年、123-144 頁。

2）熊谷公男「蝦夷の誓約」『奈良古代史論集』1、奈良古代史談 話会、1985 年、15-26 頁。今泉隆雄「蝦夷の朝貢と饗給」『東 北古代史の研究』、吉川弘文館、1986 年、105-155 頁。今泉隆 雄「飛鳥の須彌山と齋規」『古代宮都の研究』、吉川弘文館、 1993 年、2-63 頁。

3）たとえば、次は、須彌山石は崦崙山として造形されたものでは
ないかとする。和田萃 『飛鳥』岩波新書 850、岩波書店、2003 年、131-132 頁。また、次は、須彌山石は道教思想にもとづい て造られたものと考えている。河上邦彦『飛鳥発掘物語』産経 新聞ニュースサービス、2004年、214-210 頁。

4）長岡龍作「須尔座考一薬師寺金堂薬師如来像の台座をめぐって」 『日本上代における仏像の荘厳』研究成果報告書、奈良国立博 物館、2003 年、139-149 頁。谷口耕生「総説・神仁習合美術に 関する覚書」『特別展・神仏習合』奈良国立博物館、2007 年、 6-16 頁。吉澤语「須尔山石」『特別展・神仏習合』奈良国立博 物館、2007 年、 255 頁。

5）文化力誇示のための装置と見なす早い例として、たとえば次が あげられる。矢島恭介・前掲注 1、1949年、324頁。

6）隋の煬帝の散楽について、次はすぐれた論考である。渡辺信一 郎「隋の楽制と帝国構造-散楽と正月十五日の民間習俗」『史 學研究 252、2006 年、21-38 頁。

7) 東大寺大仏蓮弁に描かれた図については、たとえば、次がある。 前田泰次・露木惠子「東大寺大佛蓮瓣毛彫の圖柄及ひ婊現技術 についての考察」『國華』982、1975 年、9-38 頁。前田泰次・ 露木惠子「東大寺大佛蓮瓣毛彫の圖柄及び表現技術についての 考察 (續) 」『國華』1005、1977 年、19-27 頁。奥村秀雄「東 大寺大伀蓮分毛彫図の研究」『東京国立博物館紀要』12、1977 年、161-236 頁。須彌山図は、正確には蓮并に画かれた図の下 段部分に当たる。その上に画か冰た天界図については、注目寸 べき論考として次がある。稲本泰生「東大寺二月堂本尊光背図 像考一大仏蓮弁線刻図を参照して」『鹿園雜集』6、2004年、41-83 頁。

8）『日本書紀』巻 22 、推古天皇二十年是歳条「是歳。自百濟國 有化來者。…其人日。…能構山岳之形。…仍令構須彌山形及呉 橋於南庭。」

9）『日本書紀』巻 26、斉明天皇三年七月条「三年秋七月丁亥朔 己丑。覩貨邏國。男二人女四人。漂泊于筑紫。…乃以以驛召。辛 丑。作須彌山像於飛鳥寺西。且設孟蘭瓮會。暮饗酰貨邏人。」

10）熊谷公男・前掲注 $2 、 1985$ 年、 26 頁。今泉隆雄・ 前掲注 $2 、$ 1993 年、 53 頁。

11）楊昫「孟蘭盆賦」が炊のように結ばれるのが参考になろう。 「太陽夕。乘㸃歸。下端闇。入紫微。」なお、次は、以上の賦 に「奥大周如意元年秋七月。…渾元告秋。羲和奏曉。太陰望分

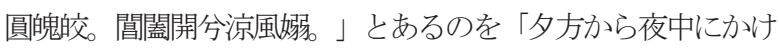
て行われたであろうことを示唆する句」であると解釈している ようであるが、その句はそうではなく「七月十五日」であるこ 
とを示寸ものであろう。小南一郎「『孟蘭盆經』から『目連變 文』へ-講經と語り物文藝とのあいだ-（上）」『東方學報』京 都 75、2003 年、81-122 頁。100-101 頁。

12）『日本書紀』巻 26、斉明天皇五年三月条「甲午。甘檮丘東之 川上。造須彌山。而饗陸奥與越蝦夷。」

13）今泉隆雄・前掲注 $2 、 1986$ 年、111-112 頁。

14）『日本書紀』巻 26 、斉明天皇六年五月条「是月。 $\cdots$ 又於石上 池邊。作須彌山。高如廟塔。以饗肅愼四十七人。」

15）今泉隆雄・前掲注 $2 、 1986$ 年、111 頁。

16）矢島恭介・前掲注 $1 、 1949$ 年、321-328 頁。

17）今泉隆雄・前掲注2、1993 年、22-23 頁。

18）奈良国立文化財研究所飛鳥資料館・前掲注 $1 、 1975$ 年、24 頁。

19）熊谷公男・前掲注 2 論文および今泉隆雄・前掲注 2 論文、さら に次を参照 北條勝貴「日本的中華国家の創出と確的的宣誓儀 礼の展開」『佛教史學研究』42-1、1999 年、1-39 頁。

20）『日本書紀』巻 20 、敏達天皇十年閏二月条「十年春潤二月。 蝦夷数千寇於辺境。由是召其鬼斗帥綾糟等。…於是綾糟等懼然恐 懼。乃下泊瀬中流。面三諸岳。漱水而盟曰。臣等蝦夷。自今以 後。子棌孫。用清明心。事奉天關。…」

21）『日本書紀』巻 25、孝徳天皇即位前紀六月条「乙卯。天皇。 皇祖母尊。皇太子。於大槻樹之下。召集群臣、盟曰。…而自今 以後。君無二政。臣無貮朝。‥」

22）今泉隆雄・前掲注 2、1986 年、134-135 頁。

23）『日本書紀』巻 27 、天智天皇十年十一月条「丙辰。大友皇子 在内董西殿織仏像前。左大臣蘇我赤兄臣。右大臣中臣金連。蘇 我果安臣。巨勢人臣。紀大人臣侍焉。大友皇子。手執香鑪 先 起誓盟曰。六人同心。奉天皇詔。若有違者。必被天罰。云々。 於是左大臣蘇我赤兄臣等。手執香鑪随次而起。泣血誓盟曰。 臣等五人。随於殿下。奉天皇詔。若有違者。四天王打。天神地 祇。亦復誅罰。三十三天。証知此事。子孫当絶。家門必亡。云々。」

24）『阿毘達磨俱舍論』巻 $11(\mathrm{~T} 29,59 \mathrm{c})$ 「論曰。三十三天。住迷盧 頂。…於山頂中。有宮名善見。…是天帝釋。所都大城。」、匹阿

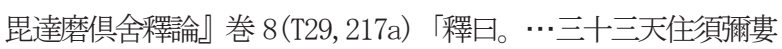
頂。‥釋曰。於須彌婁山上。帝釋及三十三天住此最勝處。 $\cdots$ 釋 曰。須彌婁山王頂。中央有大城名善見。…此城是帝釋所都之處。」

25）『阿毘達磨俱舍論』巻 $11(T 29,59 b-59 c) 「$ 論曰。蘇迷盧山。有 四層級。…此四層級。從妙高山。傍出圍繞 盡其下半。…第四 層級。四大天王。及諸脊屬。共所居止。」、『阿毘達磨俱舍釋 論』巻 8(T19, 216c-217a)「釋曰。須彌婁山。…由此四層。山王 半量。層層所圍繞 $\cdots$ 釋曰。‥四天王自身。及餘春屬 住第四
層。」

26）たとえば、次を参照。望月信亨編・塚本善隆等増補『望月佛教 大辭典』1、世界聖典刊行協会、1974 年、243-244 頁。総合佛 教大辞典編集委員会編集『総合佛教大辞典』、法藏館、1987 年、 93-94 頁。近年の論考としては、次が参考になる。小南一郎・ 前掲注 11、2003 年。

27）『佛説孟蘭盆經』巻 $1(\mathrm{~T} 16,779 \mathrm{~b}) 「$ 佛言。汝母罪根深結。非汝 一人力所奈何。汝雖孝順。聲動天地。天神地神。邪魔外道。道 士四天王神。亦不能奈何。當須十方眾僧。威神之力。乃得解脫。 吾今當爲汝説。救濟之法。令一切難。皆離憂苦。罪障消除。」

28）北條勝貴・前掲注 19、1999 年、5-8 頁。

29）中路正恒『古代東北と王権』講談社現代新書 1559、講談社、 2001 年、172-173 頁。

30）矢島恭介・前掲注 $1 、 1949$ 年、324 頁。

31）見るからに道教との関連が考えられる石人像の存在は、須彌山 石は須爾山を象徴したものではない可能性を指摘する説の論 拠となっている。和田萃・前掲注 3 論文および河上邦彦・前掲 注 3 論文を参照

32）矢島恭介・前掲注 $1 、 1949$ 年、322 頁。

33）千田稔『飛鳥一水の王朝』中公新書 1607、中央公論新社、2001 年、223-226 頁。

34）なお、正確には、次によれば、隋代以前においては、散楽は百 戯と呼ばれていた。『通典』巻 146、樂 6 「散楽、隋以前謂之 百戲。

35）『隋書』巻 13、音樂志上「二十六、設長蹻伎。二十七、設須 彌山、黄山、三峽等伎。二十八、設跳鈴伎。二十九、設跳劍伎。 三十、設橂倒伎。」

36）『通典』巻 146、樂 6 「大抵散樂雜戲多幺術。皆出西域。…梁 有長蹻伎、跳鈴伎、躑倒伎、跳劍伎，今並存。‥透三峽伎，蓋 今之透飛梯之類也。」

37）『隋書』巻 15 「始齊武平中。有魚龍爛漫、俳優、朱儒、山車、 巨象、拔井、種瓜、殺馬、剥驢等。奇怪異端 百有餘物。名爲 百戲。周時。鄭譯有龍於宣帝。奏徵齊散樂人。並會京師爲之。 蓋秦角抵之流者也。開皇初。並放遣之。及大業二年。突顸染干 來朝。煬帝欲誇之。總追四方散樂。大集東都。初於芳華苑積翠 池側。帝帷宮女觀之。…文有神鼇負山。幻人吐火。千變萬化。 曠古莫儔。染干大駭之。自是皆於太常教習。毎歳正月。萬國來 朝。留至十五日。於端門外。建國門内。綿亘八里。列爲戲場。 百官起棚夾路。從昏達旦。以縱觀之。至晦而罷。‥三年。駕幸 榆林。突厥啓民。朝于行宮。帝又設以示之。六年。諸夷大獻方 
物。突厥啓民以下。皆國主親來朝賀。乃於天津街盛陳百戲。自 海内凡有奇伎。無不總萃。崇侈器玩。盛飾衣服。皆用珠翠金銀。 錦罣絺繡其營費鉅億萬。…百戲之盛。振古無比。自是毎年以 爲常焉。」

38）『隋書』巻 3 「六年春正月。 $\cdots 丁$ 丁丑。角抵大戲。於端門街。天 下奇伎。異藝畢集。終月而罷。帝數微服往觀之。己丑。倭國遣 使貢方物。」および、渡辺信一郎・前掲、2006 年、33 頁。

39）今泉隆雄・前掲注 2、1993 年、16-19 頁。

40）前掲注 3 を参照。

41）たとえば、『大智度論』との関連を強調するものとして、次が ある。松本伸之「東大寺大仏蓮弁線刻画の図様について」『南 都佛教』55、1986 年、52-70 頁。

42）たとえば、『世記經』では、四層については必ずしも明確では なく、須彌山の断面の形も不明である。『起世經』では、須彌 山は上広下狭で四層の間䛿は不明であるばかりか、あるいは三 層である可能性もある。『立世論』では、第四層は須彌山の三 分の二の高さにある。『婆沙論』では、四層の位置と間隔は『俱 舍論』に同じであるが、断面は上狭下広である。『大智度論』 では、四層については不明である。『瑜伽論』では、四層の間 隔が不明である。『正法念處經』では、四層は明確ではなく、 あるいは五層であるようにも思われる。また、『立世論』、『大 智度論』、『瑜伽論』では、四天王は須彌山に住んでいないよ うである。詳しくは、稿を改めたい。

43）『大唐西域記』巻2「夫數量之稱。謂踰綪那。（舊曰由旬。又 曰踰闍那。又曰由延。皆叱略也)。踰綪那者。自古聖王一日軍 行也。舊傳一踰繥那四十里矣。印度國俗乃三十里。聖教所載唯 十六里。さらには、次を参照。塚本善隆（編代表）『望月佛 教大辭典』5、世界聖典刊行協会、1963 年、4926 頁、「由旬」。

44）『阿毘達磨俱舍論』巻 $11(\mathrm{~T} 29,57 \mathrm{c})$ 「論曰。 $\cdots$ 如是九山。住金 輪上。入水量皆等。八萬踰繥那。蘇迷盧山。出水亦爾。」、『阿 毘達磨俱舍釋論』巻 $8(\mathrm{~T} 29,214 \mathrm{c})$ 「釋曰。於金地上有水。深八 萬由旬。此中諸山次第入中。…釋曰。如此須彌婁山。高一十六 萬由旬。」

45）『阿毘達磨俱舍論』巻 $11(\mathrm{~T} 29,59 \mathrm{c})$ 「論曰。 $\cdots$ 其頂四面。各八 十千。與下四邊。其量無別。」、『阿毘達磨俱舍釋論』巻 8(T29, 217a)「釋曰。…有餘師説。一邊各。八萬由旬。如下 際。此名最勝處。有餘師説。於須彌婁頂中央。一邊各。二萬 由旬。周圍八萬由旬。為最勝處。三十三天。於其中住。」

46）ただし、『俱舍論』の示寸ところは、鼓のように中央がくびれ た形である可能性もある点は次を参照。『俱舍論記』巻 11
(T41, 189a）「若妙高如鼓。‥」、『俱舍論疏』巻11（T41, 618b) 「中腰細也。」

47）『阿毘達磨俱舍論』巻 $11(\mathrm{~T} 29,59 \mathrm{c})$ 「論曰。 $\cdots$ 其頂四面。各八 十千。與下四邊。其量無別。有餘師説。周八十千。別説四邊。 各唯二萬。」、『阿毘達磨俱舍釋論』巻 8(T29, 217a)「釋曰。 …有餘師説。一邊各。八萬由旬。如下際。此名最勝處。有餘 師説。於須彌婁頂中央。一邊各。二萬由旬。周圍八萬由旬。 為最勝處。三十三天。於其中住。」

48）『阿毘達磨大毘婆沙論』巻 $133(\mathrm{~T} 27,691 \mathrm{c})$ 「山頂四面。各二十 千。若據周圍。數成八萬。有餘師説。面各八十千。與下際四邊。 其量正等。」

49）『阿毘達磨順正理論』巻 31 (T29, 518c)「論曰。…其頂四面。 各二十千。若據周圍。數成八萬。有餘師説。面各八十千。與下 際四邊。其量無別。」

50）『阿毘達磨俱舍論』巻 $11(\mathrm{~T} 29,59 \mathrm{c})$ 「論曰。 $\cdots$ 山頂四角。各有 一峰。其高廣量。各有五百。有藥叉神。名金剛手。」、『阿毘 達磨俱舍釋論』巻 $8(\mathrm{~T} 29,217 \mathrm{a})$ 「釋曰。須彌婁四維。各有一峯。 此峯徑五百由旬。高量亦爾。有夜叉神。名金剛手。」

51）『阿毘達磨俱舍論』巻 11 (T29, 59c-60a）「論曰。…於山頂中有 宮。名善見。 $\cdots$ 是天帝釋。所都大城。」、『阿毘達磨俱舍釋論』 巻 8(T29, 217a)「釋曰。須彌婁山王頂。中央有大城名善見。 $\cdots$ 此城是帝釋所都之處。」

52）前掲注 42 を参照。

53）『阿毘達磨俱舍論』巻 11 (T29, 59b) 「頌曰。妙高層有四。相去 各十千。傍出十六千。八四二千量。堅手及持筤。恒憍大王眾。 如次居四級。」、『阿毘達磨俱舍釋論』巻 $8(\mathrm{~T} 29,216 \mathrm{c}-217 \mathrm{a})$ 「偈曰。山王層有四。相去各十千。…偈曰。十六八四二千由旬 傍出。…偈曰。俱盧多波尼。持临恒醉神。諸四大王天」

54）『阿毘達磨俱舍論』巻 $11(T 29,59 b-59 c)$ 「論曰。蘇迷盧山。有 四層級。始從水際。盡第一層。相去十千。踰繵那量。如是乃至。 從第三層。盡第四層。亦十千量。此四層級。從妙高山。傍出圍 繞。盡其下半。最初層級。出十六千。第二第三。第四層級。如 其次第。八四二千。有藥叉神。名爲堅手。住初層級。有名持䯭。 住第二級。有名恒憍。住第二級。此三皆是。四大天王。所部天 眾。第四層級。四大天王。及諸春屬。共所居止。」、『阿毘達 磨俱舍釋論』巻 $8(T 29,216 \mathrm{c}-217 \mathrm{a})$ 「釋曰。須彌婁山。從水際取 初層。中間相去。十千由旬。乃至第四層。相去亦爾。由此四層。 山王半量。層層所圍繞。此四層次第出。復有幾量。…釋曰。初 層從須彌婁。傍出十六千由旬。第二八千。第三四千。第四二千 由旬出。何眾生得住此中。…釋曰。有夜叉神。名俱盧多波尼。 
住初層。復有諸天神。名持㷃。住第二層。復有天神。名恒醉。 住第三層。如此等皆是。四大王天軍眾。四天王自身。及餘脊屬。 住第四層。如於四層中。四大王天脊屬住。」

55）前田泰次・露木惠子・前掲注 7、1975 年、33 頁。

56）『阿毘垟磨俱舍論』巻 $11(T 29,61 c)$ 「論曰。 …故世尊言。大龍 有八。皆住一劫。能持大地。」、『阿毘達磨俱舍釋論』巻 9(T29, 219b) 「釋曰。…佛世尊説。比丘有八部龍。名大龍。皆 一劫住。持於地輪。」

57）『阿毘達磨俱舎論』巻 $11(\mathrm{~T} 29,57 \mathrm{~b})$ 「論曰。於金輪上。有九大 山。妙高山王。處中而住。餘八周匝。繞妙高山。於八山中。前 七名内。第七山外。有大洲等。此外復有。鐵輪湋山。周互如輪 圍一世界。」、『阿毘達磨俱舍釋部』巻 8 (T29, 214b)「釋曰。 如此等山。依金地輪上住。八大山中央。有須彌婁山。所餘山。 繞頑了爾婁住。一由乾陀羅。二伊沙陀羅。三佉特羅柯山。四修騰 婆那。五阿輸割那。六毘那多柯。七尼旻陀羅。此須彌婁山。七 山城所圍。最外山城。名尼旻陀羅。…釋曰。於第七山外。有四 大洲。於四大洲外。復有鐵輪璐山。由此山故。世界相圓。如輪 於中。」

58）『阿毘垟磨俱舎論』巻 $11(T 29,57 \mathrm{c}-58 \mathrm{a})$ 「論曰。於外海中。大 洲有四。謂於四面。對妙高山。南瞻部洲。北廣南陝。三邊量等。 其相如車。南邊唯廣。三踰繥那半。三邊各有。二千踰繥那。 $\cdots$ 東勝身洲。東陝西廣。三邊量等。形如半月。東三百五十。三邊 各二千。西牛貨洲。圓如滿月。徑二千五百。周圍七千半。北俱 盧洲。形如方座。四邊量等。面各二千。」、『阿毘達磨俱舍釋 論』巻 8(T29, 215a)「釋曰。有四大洲。對須彌串四邊。‥釋曰。 於此海中。炏浮洲。一邊二千由旬。三邊等量。其相似車。…釋 曰。此第四邊廣量三由旬半。是故此洲似車相。…釋曰。從此洲 向東。對須彌串邊有洲。名弗波毘提訶。出海上。其相如半月。 若約邊量。…釋曰。此洲三邊。如剡浮洲三邊。量各二千由旬。 …釋曰。是第四邊。廣二百五十由旬。…釋曰。從此洲向西。對 須彌婁邊有洲。名阿婆羅酄陀尼洲。邊量七千五百由旬。此洲相 圓如滿月。‥釋曰。中央廣二千五百由旬。‥釋曰。從此洲向北。
對須彌婁邊有洲。名根多羅鳩婁洲。邊量八千由旬。四角思方。 其相似比陀訶。四邊量等。如一邊二千由旬。」

59）玉虫厨子の例については、たとえば次を参照。片岡直樹「第九 章玉蛭子」『法隆寺美術（論争の視点）』、グラフ社、1998 年、257-284 頁。四川省成都市万仏寺遺址出土の例については、 たとえば次を参照「「120 須弥山図浮彫」『中国国宝展』、東 京国立博物館、2000 年、180 頁。および片山寛明「154 須弥山 図浮彫」『中国・美の十字路展』、大広、2005 年、182 頁。

60）龍については、あるいは中石と下石の間にかつては龍が刻され た個所があったかもしれない。

61）奈良国立文化財研究所飛鳥資料館・前掲注 1、1975 年、24-25 頁。

\section{捰図出典：}

図 1 Asuka Historical Museum (comp.), William R. Carter (trans.): "Guide to the Asuka Historical Museum": Nara National Cultural Properties Research Institute 1978, p.25

図2 Hashimoto, Shôen: 'Die Kosmologie der Kegon-Lehre am Beispiel der Darstellung der "Lotosblütenschatzwelt" auf dem Lotossockel des Großen Buddha', aus dem Japanischen übersetzt und für den Katalog bearbeitet von Jörg B. Quenzer. In: "Im Licht des Großen Buddha" Museum für Ostasiatische Kunst Köln 1999, S.43, Abb.17

図 3 Asuka Historical Museum (comp.), William R. Carter (trans.): Id. 1978,p.21

図4 今泉隆雄「飛鳥の須彌山と齋槻」『古代宮都の研究』、吉川 弘文館、1993 年、13 頁。

図 5 玉蟲厨子密陀絵模写須弥山図、東京国立博物館情報ア一カイ ブ、画像番号C0016059、列品番号P-427

図6 東京国立博物館・朝日新聞社（編）『中国国宝展』、朝日新 聞社、2000 年、180 頁、120 須弥山図浮彫。

図 7 Asuka Historical Museum (comp.), William R. Carter (trans.): Id. 1978, p.25 
Abstract: A widely supported new hypothesis argues that the so-called Mt. Sumeru Stone ( 7 century CE) of Asuka was a device for a ritual, in which the foreign barbarians swore obedience to the Imperial court of Japan at the time. The ritual is believed to have been a sacred or magical ritual related to Indra and the Four Heavenly Kings. Quoting the Buddhist scripture Abhidharma-kośa-śāstra, the advocates of this theory even explain that the morphological common points between the stone and the so-called Mt. Sumeru Drawing ( 8 century CE) on a petal of the throne of the Great Buddha Statue in Tōdaiji temple indicate that the stone really symbolizes Mt. Sumeru or the central mountain in a Buddhist world. However, this hypothesis is unacceptable either philologically or iconographically. Carefully analyzing the contents of Nihonshoki, Chinese historical texts, Abhidharma-kośa-sāstra and other texts, this paper suggests that the stone should be regarded as a device, like the circuses held by the order of Emperor Yangdi (r. 604-617 CE) of the Sui dynasty of China, to demonstrate the cultural power of the state to the foreigners. Furthermore, this paper illustrates that the stone has no clear relationship with Abhidharma-kośa-śāstra, although the drawing likely have been made on the basis of the sasastra. More studies are needed to clarify the exact meaning of the design of the stone. 